SECTION: PSYCHOTHERAPEUTIC MODALITIES, METHODS AND METHODOLOGIES

\author{
РОЗДІЛ: ПСИХОТЕРАПЕВТИЧНІ МОДАЛЬНОСТІ, МЕТОДИ ТА МЕТОДИКИ
}

\title{
EFFECTS AND CHALLENGES REGARDING SUPERVISION IN PALLIATIVE CARE TEAMS: RESULTS OF A 5-YEAR STUDY IN SOUTH TYROL (ITALY)
}

\author{
- Klaus Garber ${ }^{\mathrm{a}, 1}, P h . D$. \\ (Dalvatore Giacomuzzi ${ }^{1}$, Doctor Sc. habil, Ph. D. \\ Katrin Gapp ${ }^{2}$, Ph. D. \\ Maria Luise Obexer ${ }^{2}$ \\ Anna Goegele-Blasbichler ${ }^{2}$, Master \\ Adolf Engl ${ }^{2}, P h . D$. \\ (DIvan Titov ${ }^{3}, P h . D$. \\ Markus Ertt ${ }^{4}$, Master \\ Martin Rabe ${ }^{3}, P h . D$. \\ -Kira Sedykh ${ }^{3}$, Doctor Sc. habil \\ Oleksandr Kocharian ${ }^{5}$, Doctor Sc. habil \\ (D) Natalia Barinova ${ }^{5}$, Ph. D.

\begin{abstract}
${ }^{1}$ University of Sopron, Hungary; Department of Psychology, Sigmund Freud University, Vienna, Austria ${ }^{2}$ Institute for General Medicine, Province College for Health-Care Professions "Claudiana”, Bolzano, Italy

${ }^{4}$ Bureau for statistical studies, Innsbruck, Austria

${ }^{5}$ V. N. Karazin Kharkiv National University, Kharkiv, Ukraine ${ }^{a}$ Corresponding Author: klaus.garber@sfu.ac.at; klaus.garber@rolmail.it
\end{abstract} \\ ${ }^{3}$ University of Sopron, Hungary; Poltava V. G. Korolenko National Pedagogical University, Poltava, Ukraine
}

Objective: Evaluating a solution-oriented clinical supervision to improve the quality of care. Design: We performed a randomized, longitudinal controlled trial. A total of 32 health districts were involved in the study. For the evaluation of the intervention, the following dimensions were collected as indicators of the quality of supervision: Quality of life (FACT-G, SF12, POS), psychological stress, depression, burn-out (HADS, BDI-II, VAS scales, HPS), sense of coherence (SOC-13), satisfaction with care, communication and support from the patients and relatives (VAS scales) and working conditions (COPSOQ) from the nursing staff and family doctors. Results: Of the 85 subscales, the SOC Nursing Sum Score ( $p=0.017)$, the SF-12 Nursing Sum Scale ( $p=0.036$ ), and the COPSOQ Scales of General Practitioners showed significant differences in developmental opportunities $(\mathrm{p}=0.020)$, leadership $(\mathrm{p}=0.003)$, social support $(\mathrm{p}=0.001)$ and community spirit $(\mathrm{p}=0.024)$. At the second point time of the study, significant differences were found in the subscales of the Palliative Care Outcome Scale (POS) and the subscale of the test instrument Functional Assessment of Cancer Therapy - General (FACT-G) FUNCTIONAL WELL-BEING of the patients. The satisfaction values of nurses and general practitioners with the supervision showed an extremely positive assessment of both nurses and general practitioners regarding supervision. Conclusions: Supervision affects positively the process of palliative home care. It seems important to adjust the number of supervision meetings according to the needs of the individual team in order to achieve an optimized team performance.

Keywords: team supervision; palliative care; end-of-life care; physician perspectives

(C) K. Garber, S. Giacomuzzi, K. Gapp, M.-L. Obexer, A. Goegele-Blasbichler, A. Engl, I. Titov, M. Ertl,

M. Rabe, K. Sedykh, O. Kocharian, N. Barinova, 2020 


\section{Introduction}

Palliative Care is an approach to improve the quality of life of both, patients suffering from a serious terminal illness and their families. Consideration of physical, psychosocial and spiritual domains and optimal symptom control are crucial in palliative care.

Still little is known regarding healthcare for cancer patients treated mainly at home during the time before they die. In France, home management during the last month of life is even uncommon and when it is occurs, in one out of two cases patients pass away in a hospital setting (Tuppin, 2019). Even though patients had everything they needed in the hospice, their main thoughts were always focused on human relationships (Monaco, 2019). Therefore, also the palliative care unit members are part of those experienced human relationships.

It is known that there are multiple challenges working in intensive care units. Especially emotional demands are high for patients, family caregivers and health professionals, such as nurses and general practitioners. Palliative care units work often long hours without supervision in ill-designed wards.

This emotional stress has the potential to impair the wellbeing and quality of life also of both, family caregivers and health professionals, thereby affect patient care. These challenges may result in high levels of occupational stress, burnout, compassion fatigue, and posttraumatic stress disorder or secondary traumatic stress, which further contributes to attrition rates. In other studies, also a statistically significant correlation between level of job satisfaction and the level of burnout and between the level of stress and the emotional exhaustion and depersonalization domains could be found (McDermid, 2019, Saravanabavan, 2019).

General practitioners and nurses in collaboration with family caregivers and specialists are the supporting pillars for palliative home care in rural areas like South Tyrol. Palliative care in general and particularly in palliative home care requires a high degree of commitment from all involved people and a good communication network. The results of a pilot study showed that palliative specialist home staff rated quality of communication within the team, which plays a crucial role in palliative care, as "rather moderate" (Engl, 2013). This trial addresses the need for intervention in the fields of team communication and cooperation, dialogue with patients and family, patient centred care and the handling of emotional stress of nurses and general practitioners.

In this study a solution-oriented clinical supervision was evaluated in terms of implications on quality of care, improvement of communication techniques, interpersonal skills, better collaboration of health professionals (networking) and better cooperation with patients and family caregivers.

\section{Material and Methods}

The study was approved by the ethical committee (Ethics committee of Bolzano; 21/05/2014; ref. $30 / 2014)$. Informed written consent was obtained from all patients. We performed a randomized, longitudinal study. As a study design for evaluating the effects of the intervention (supervision), the psychological test instruments listed below were surveyed at three points in time in a longitudinal section.

The case number analysis was based on the central hypothesis that more favourable changes in the dimensions quality of life as primary endpoint and symptom control, depression and satisfaction (support and communication), and collaboration as secondary endpoints in the intervention group are expected compared to the control group.

The study population was therefore divided randomly into two groups, a control group (without interventions) and an intervention group (topiccentred supervision). A total of 32 health districts were involved in the study. The health districts were randomly assigned to 16 each group. Half of the health districts were randomly assigned to the intervention group and half to the control group, and the doctors' practices were assigned according to the unit to which they belonged. All practices of general practitioners in private practice were taken into account in the study.

The inclusion criterion was the entire province of South Tyrol, the voluntary consent to participate in the study on the part of the patient, doctors, nursing staff and relatives.

After a random division of health care into intervention and control groups, patient recruitment 
was then carried out consecutively. A total of 41 doctors' surgeries took part.

A total of 41 palliative patients in the control group $(\mathrm{M}=72.8 ; \mathrm{SD}=12.2$ years; $55.8 \%$ male, $44.2 \%$ female) and 43 in the intervention group ( $\mathrm{M}=76.3$; SD 10.5 years; $51.2 \%$ male; $48.8 \%$ female) were accompanied.

A total of 43 nurses were enrolled in the intervention group and 40 in the control group. The percentage of women was $97.7 \%$ in the intervention group and $97.5 \%$ in the control group. The mean age was $47.4(\mathrm{SD}=8.2)$ years in the control group and $46.9(\mathrm{SD}=6.3)$ years in the intervention group ( $>0.050$ ). Among the general practitioners, a total of 41 general practitioners in the intervention group (63.4\% men; $36.6 \%$ women) and 40 doctors in the control group ( $80 \%$ men; $20 \%$ women) were participating in the study. The mean age of the physicians in the intervention group was 55.2 $(\mathrm{SD}=7.9)$ years and that of the control group 59.3 $(\mathrm{SD}=6.6)$ years $(\mathrm{p}>0.050)$.

\section{Supervision issues}

Supervision is methodologically based on a systemic solution-oriented approach, but also includes a topic-centred approach. The supervision method used in the study was a "topic-centred team and case supervision" with included training elements. This special "topic-centred supervision" is a counselling and support procedure in which, in addition to the classical questions of supervision, the main topics of care for palliative patients and their relatives are also taught and counselling is provided in relation to the concrete case study.

In its orientation, this supervision is also based on the systemic self-model (Garber, 2010). Working with the systemic self-model has proven to be an efficient aid to reflection on one's own professional and private dynamics (narratives), especially in short-term supervision and coaching, which changes one's perspective (Garber, 2009). The topics of supervision are viewed and worked on from a systemically oriented narrative perspective. Since supervision, in addition to the case supervision character, is also a supervision centred on specific topics, an extended approach also incorporates methodological approaches from Ruth Cohn's
Theme-Centred

Interaction

(TCI)

(Langmaack, 1994).

The supervisors had to pay attention to the following criteria:

- The supervisors should have the appropriate qualifications to guarantee a consistent methodological approach and to meet the questions and objectives of the study. Therefore, the supervision team consisted of a female physician and a male supervisor

- Targeted selection of the supervisors according to the criteria - male/female, interdisciplinary between the fields of medicine (with a special specialisation in palliative care), psychology (clinical - health and psychosocial area)

- Good balance between the frequency of supervision units

- Selection of a suitable method of short-term supervision, with elements of specific training in the field.

The following topics were covered:

- Topics proposed by the supervisors

- Personal conversation styles with patients and nursing staff as well as in the network partners of the supervisors

- Specific methods of conducting conversations (doctor - nurse - patient - conversations; conversations with relatives, network conversations, forms of networking and case planning

- Healthy professional relationship regulation between doctor/nurse - patient, in the professional team and in the sanitary and psychosocial network.

- Dealing with topics such as grief, death, emotionally stressful professional situations and other topics that affect this field.

- Relief from negative feelings, which arise from the care

- Awareness of patient-centred care

- Team effort

It was important to find a good balance of frequency regarding the number of supervision meetings. Increased supervision session could result in increased stress, therefore result in a negative effect of the dependent variable. Few supervision meetings would result in the desired positive effect on the dependent variables. There were two threehour supervision appointments per patient. A further 
appointment took place post mortem. In addition, the intervention group was asked for other important and relevant data on the organisation, training needs and priority issues of palliative care. In cases where the palliative patients had died between the two supervision appointments, the team of specialists decided to carry out these visits anyway.

Regarding the personnel judgement on supervision we applied a questionnaire that focused on the performed supervision which consisted of 32 items and four superordinate questions. The questions cover the overall satisfaction with supervision, the fulfilment of expectations of supervision and the assessment of the professional and social competence of the supervisor. The questions were to be answered on a 100-step visual analogue scale, whereby the value 0 represents the degree of "not at all satisfied" and the value 100 the degree of "completely satisfied".

However, it should be noted that only the professional groups of nurses and general practitioners received supervision.

For the evaluation of the intervention, the following dimensions were collected as indicators of the quality of supervision: Quality of life (FACT-G, SF12, POS), psychological stress, depression, burnout (HADS, BDI-II, VAS scales, HPS), sense of coherence (SOC-13), satisfaction with care, communication and support from the patients and relatives (VAS scales) and working conditions (COPSOQ) from the nursing staff and family doctors (Fig. 1).

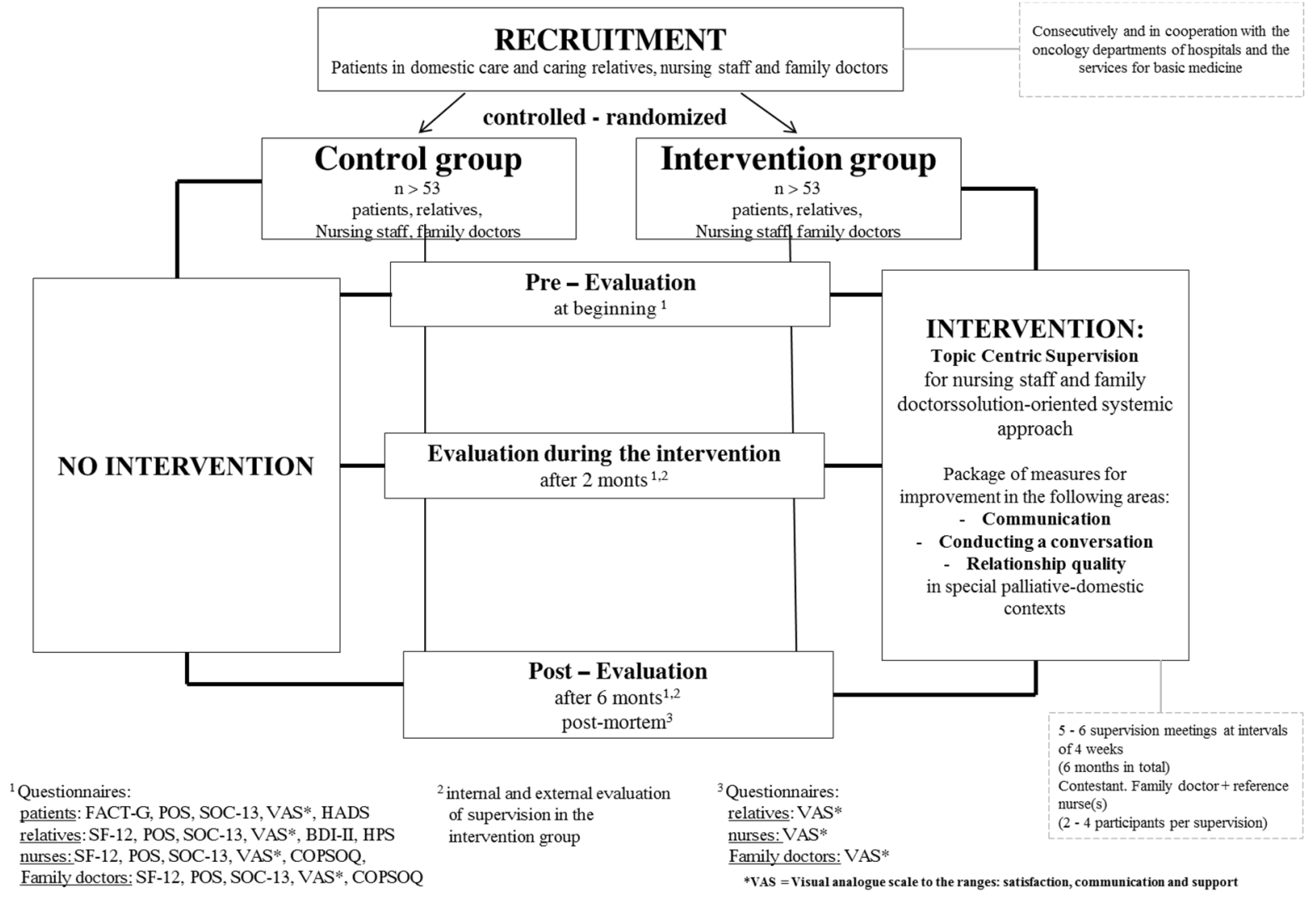

Figure 1. Study design

Health-related quality of life, with a focus on psychosocial aspects, was chosen as the primary endpoint (FACT-G, SF12, POS) as an indicator of the quality of care and evaluation of supervision.

The dimensions psychological stress, depression, burn-out (HADS, BDI-II, VAS scales, HPS, COPSOQ), sense of coherence (SOC-13), satisfaction with care, communication and support from patients and caring relatives (VAS scales) and working conditions (COPSOQ) from nurses and GPs are used as secondary endpoints.

In addition, protocols, observations and findings of participants and supervisors were taken into account. Finally, a survey was conducted after the death of the patients ("post mortem") on the satisfaction dimensions of the care provided by 
relatives and the evaluation of nurses and family doctors.

For the calculation of the optimal visual sample size, an average effect strength (Cohen's $d=0.5$ ) is assumed due to the lack of availability of comparative data from the technical literature. In addition, an alpha error of 0.05 and a beta error of 0.2 as well as a test strength of $80 \%$ are used as calculation basis. An optimal sample size of 50 subjects per group was calculated (taking into account the alpha and beta error probability as well as the test strength). Furthermore, a margin for a possible deviation of the data from the normal distribution of 5 percent should be added to the optimal sample size. Thus, the optimal sample size is 53 subjects per group.

The Functional Assessment of Cancer Therapy General (FACT-G) was developed to measure QoL (Quality of Life) in cancer patients receiving therapy. While the FACT-G is widely used across diverse cancer patient populations, it was not initially developed to monitor QoL of patients over a longer follow-up period or for patients in remission or on observation. It was initially validated using classical test theory (CTT) methodology in a heterogeneous sample of 545 patients with cancer, $8 \%$ of whom had either leukemic cancer or a lymphoma. The FACT-G subscales and total score demonstrated good internal consistency reliability, convergent validity and known-groups validity (Cella, 1993, Yost, 2013).

The SOC (Sense of coherence) was originally defined by Antonovsky. Therefore, the SOC concept is composed of three important components (a) Comprehensibility, (b) Manageability and (c) Meaningfulness, which are related to each other. These three components are within the person's Sense of Coherence. The original version consists of 29 (SOC-29), while the abbreviated version consists of 13 items (SOC-13). The systematic review showed that, the SOC questionnaires is used in more than 48 countries in total. Both instruments were validated many times in many different population groups, from general population to various groups of patients. The studies evaluated the reliability, mostly in terms of internal consistency, as well as various aspects of validity, e.g. face, criterion, and construct validity and can be regarded as very good (Stern, 2019).
Several instruments have been developed to assess psychosocial workload. The COPSOQ (Copenhagen Psychosocial Questionnaire) instrument covers a broad range of domains including Demands at Work, Work Organization and Job Contents, Interpersonal Relations and Leadership, Work-Individual Interface, Social Capital, Offensive Behaviors, Health and Wellbeing. Previous versions of the COPSOQ were developed through factor analyses of a large range of items, and reliability of resulting scales was subsequently tested (Burr, 2019). The slightly stronger association between psychosocial workload as assessed by COPSOQ and burnout might be explained by its broader approach (Nuebling, 2013).

QOL was measured using the SF- $12^{\circledR}$ Health Survey (version 2.0), a validated shortened version of SF-36. The physical and mental component scores which range from 0 to 100 . With the population means at 50, higher scores indicate better physical and mental QOL, respectively (Ware, 1998).

The palliative outcome scale (POS) emerged as an important tool for measuring outcomes to assess the quality of life of patients and families, of the quality of care provided and the service organization (Rugno, 2016). The international scientific literature on the application of POS proved to be relevant to the advancement and consolidation of the field of knowledge related to palliative care. The POS is a multi-dimensional assessment scale of QoL widely used, both in teaching and research as well as in clinical practice, applied in people suffering lifethreatening chronic diseases in Palliative Care (PC) (Rugno, 2016, Wentlandt, 2012).

The Hospital Anxiety and Depression Scale (HADS) is a brief and widely used instrument to measure psychological distress in cancer patients and it is available in French, German, Dutch, Italian, Spanish, Chinese, and Arabic.

It has been shown that the HADS gives clinically meaningful results as a psychological screening tool, in clinical group comparisons and in studies with several aspects of disease and quality of life. It is sensitive to change both during the course of disease and in response to medical and psychological interventions (Herrmann 1997, Montazeri, 2003). 
The choice for both subscales (HADS-D / A) were defined by $\geq 8$ to be appropriate.

The BDI-II modified the BDI to address concerns with early versions of the scale and to better reflect DSM-IV/V diagnostic criteria for depressive disorders. The BDI-II is internally consistent. The BDI-II scores showed good internal consistency with a Cronbach's coefficient alpha of 0.89 , and the score interpretations had good convergent validity $(\mathrm{r}=0.74)$ and discriminant validity $(\mathrm{r}=-0.42)$. A three-factor solution of cognitive, affective, and somatic symptoms emerged using a principal components analysis with oblique rotation (Hobkirk, 2015; Beck, 1996).

Traditionally, the visual analogue scale (VAS) has been proposed to overcome the limitations of ordinal measures from Likert-type scales. A VAS (visual analogue scale) is typically presented as a horizontal line, anchored with two verbal descriptors at the extremes where respondents indicate their perceived status by placing a mark along the horizontal line at the most appropriate point.

VASs are easy to understand, administer, and score, especially when the VAS is implemented with a computer or a lineal (Sung, 2018).
The Häusliche-Pflege-Skala (HPS) was applied to obtain a quick overview of the stress situation of caregiving relatives. The questionnaire is completed by the carers themselves who care for someone with chronic assistance or care needs at home. The result provides initial indications of suitable relief measures. In addition, the HPS is suitable for crosssectional and follow-up examinations to record the subjective total burden of home caregivers. The retest reliability (measurement repetition after 14 days) is $r=.94$. The internal consistency of the overall scale is $\alpha=.91$ (Cronbach's Alpha). The split-half reliability (Pearson correlation) is $\mathrm{r}=.82(\mathrm{Gräßel}, 2011$.

\section{Results}

Table 1 shows the baseline data sets regarding the applied questionnaires that were mostly well comparable. Of the 85 subscales, only the SOC Nursing Sum Score $(\mathrm{p}=0.017)$, the SF-12 Nursing Sum Scale $(p=0.036)$, and the COPSOQ Scales of General Practitioners showed significant differences in developmental opportunities $(\mathrm{p}=0.020)$, leadership ( $\mathrm{p}=0.003)$, social support $(\mathrm{p}=0.001)$ and community spirit $(\mathrm{p}=0.024)$.

Table 1. Comparison of the test results with at least a low effect strength (Cohen's $d>0.5)$ at baseline

\begin{tabular}{|c|c|c|c|c|c|c|c|c|}
\hline & \multicolumn{6}{|c|}{ Study groups } & \multirow[b]{3}{*}{ Cohen's d } & \multirow[b]{3}{*}{ p-value ${ }^{1}$} \\
\hline & \multicolumn{3}{|c|}{ Intervention group } & \multicolumn{3}{|c|}{ Control group } & & \\
\hline & $\mathbf{N}$ & $\mathbf{M}$ & Sd & $\mathbf{N}$ & M & Sd & & \\
\hline SOC Total score nurse $t^{2}$ & 16 & 81.5 & 23.5 & 24 & 65.9 & 19.3 & 0.73 & $0.017 *$ \\
\hline $\begin{array}{r}\text { SF-12 PSYCHICAL SUM } \\
\text { SCALA (Standard: US standard } \\
\text { 1990) Nurses } t 1^{3}\end{array}$ & 15 & 53.5 & 5.9 & 21 & 47.5 & 9.2 & 0.79 & $0.036^{*}$ \\
\hline $\begin{array}{r}\text { Relationship between work and } \\
\text { private life (work-privacy } \\
\text { conflict) COPSOQ (lower }=\text { pos.) } \\
\text { General practitioners } t 1^{4}\end{array}$ & 13 & 59.6 & 16.1 & 23 & 45.9 & 28.5 & 0.61 & 0.226 \\
\hline $\begin{array}{r}\text { Decision scope COPSOQ } \\
\text { (high=pos.) General } \\
\text { practitioners } t 1^{4}\end{array}$ & 13 & 58.0 & 19.6 & 23 & 69.8 & 17.7 & 0.63 & 0.093 \\
\hline $\begin{array}{r}\text { Development opportunities } \\
\text { COPSOQ (high=pos.) General } \\
\text { practitioners } t 1^{4}\end{array}$ & 13 & 76.4 & 8.9 & 23 & 86.1 & 13.7 & 0.86 & $0.020^{*}$ \\
\hline
\end{tabular}


Psychotherapeutic Modalities, Methods and Methodologies

\begin{tabular}{|c|c|c|c|c|c|c|c|c|}
\hline & \multicolumn{6}{|c|}{ Study groups } & \multirow[b]{3}{*}{ Cohen's d } & \multirow[b]{3}{*}{ p-value } \\
\hline & \multicolumn{3}{|c|}{ Intervention group } & \multicolumn{3}{|c|}{ Control group } & & \\
\hline & $\mathbf{N}$ & $\mathbf{M}$ & Sd & $\mathbf{N}$ & $\mathbf{M}$ & Sd & & \\
\hline $\begin{array}{r}\text { Commitment to the workplace } \\
\text { COPSOQ (high=pos.) General } \\
\text { practitioners } t 1^{4}\end{array}$ & 13 & 73.2 & 9.7 & 23 & 64.3 & 17.5 & 0.66 & 0.055 \\
\hline $\begin{array}{r}\text { social support } C O P S O Q \\
\text { (high=pos.) General } \\
\text { practitioners } t 1^{4}\end{array}$ & 9 & 11.1 & 38.2 & 21 & 60.8 & 28.9 & 1.48 & $0.001 *$ \\
\hline $\begin{array}{r}\text { Feedback COPSOQ } \\
\text { (high=pos.) General } \\
\text { practitioners } t 1^{4}\end{array}$ & 9 & 11.1 & 41.7 & 21 & 33.9 & 29.1 & 0.64 & 0.104 \\
\hline $\begin{array}{r}\text { social relations } C O P S O Q \\
\text { (high=pos.) General } \\
\text { practitioners } t 1^{4}\end{array}$ & 8 & 21.9 & 52.5 & 21 & 58.3 & 24.5 & 0.95 & 0.114 \\
\hline $\begin{array}{r}\text { Community spirit COPSOQ } \\
\text { (high=pos.) General } \\
\text { practitioners } t 1^{4} \\
\end{array}$ & 8 & 26.0 & 55.5 & 21 & 73.8 & 26.5 & 1.16 & $0.024 *$ \\
\hline $\begin{array}{r}\text { TOTAL SCALE SOCIAL } \\
\text { RELATIONS AND } \\
\text { MANAGEMENT (high=pos.) } \\
\text { General practitioners } t{ }^{4}\end{array}$ & 4 & 13.0 & 23.7 & 10 & 44.0 & 10.2 & 1.82 & 0.106 \\
\hline $\begin{array}{r}\text { General health COPSOQ } \\
\text { (high=pos.) General } \\
\text { practitioners } t 1^{4}\end{array}$ & 13 & 78.5 & 8.0 & 22 & 85.0 & 13.0 & 0.62 & 0.085 \\
\hline $\begin{array}{r}\text { Burnout COPSOQ (low = pos.) } \\
\text { General practitioners } t 1^{4}\end{array}$ & 13 & 31.4 & 18.0 & 23 & 22.1 & 15.9 & 0.55 & 0.115 \\
\hline
\end{tabular}

${ }^{1}$ p-value $(2$ sided $) *<0.050 ; * *<0.001$

${ }^{2}$ Sense of Coherence -13 items: $\mathrm{MIN}=13$ MAX $=91$

${ }^{3}$ SF-12 Sum scales (Peculiarity $0-100$ ); high values $=$ high characteristic value. expected value $=50 ; \mathrm{SD}=$ $10 .^{4}$

COPSOQ scales; range 0 (=lowest characteristic value) to 100 (=highest characteristic value)

While the SOC Nursing Sum Score and the SF-12 Mental Sum Scale show significantly more favourable regarding the initial values in the intervention group, less favourable values were found in the COPSOQ subscales Developmental Opportunities, Social Support and Community Feeling.

However, at the second point time of the study, significant differences were found in the subscales of the Palliative Care Outcome Scale (POS) and the subscale of the test instrument Functional Assessment of Cancer Therapy - General (FACT-G) FUNCTIONAL WELL-BEING of the patients, whereby the patients, relatives and nurses of the intervention group achieved less favourable values in the POS subscales than those of the control group (Table 2). In particular significant differences between the two study groups could be determined within the POS sum score wherein the control group showed the more favourable values for relatives $(p=0.009)$ and nurses $(p=0.019)$. The FACT-G FUNCTIONAL WELL-BEING score showed the more favourable values for the control group $(\mathrm{p}=0.024)$.

In Table 3 we compared the results of the postmortem questionnaire for nurses between the study groups. No spastically significant differences were found. Differences regarding the mean values 
showed the more favourable scores within the intervention group for "how often did your patient spend time with family or friends" $(\mathrm{Md}=4$ vs. 5 ; $\mathrm{p}=0.059$ ), "how often did your patient spend time alone" ( $\mathrm{Md}=2$ vs. $1 ; \mathrm{p}=0.109)$ and for "how would you assess the overall quality of care in the last days of your patient's life?" ( $\mathrm{Md}=8$ vs $6.5 ; \mathrm{p}=0.614)$.

Table 4 shows the satisfaction values of nurses and general practitioners with the supervision they received. In addition to the four superordinate questions, those 10 of a total of 32 items were selected for which the most favourable values could be determined and sorted in descending order with regard to the achieved /mean value. Remarkable here are the overall extremely positive assessments of both nurses and general practitioners regarding supervision, whereby the first-mentioned professional group achieved the more favourable values.

Table 2. Comparison of the test results with at least a low effect strength (Cohen's $d>0.5)$ at the second test time

\begin{tabular}{|c|c|c|c|c|c|c|c|c|}
\hline & \multicolumn{6}{|c|}{ Study groups } & \multirow[b]{3}{*}{ Cohen's d } & \multirow[b]{3}{*}{ p-Wert } \\
\hline & \multicolumn{3}{|c|}{ Intervention group } & \multicolumn{3}{|c|}{ Control group } & & \\
\hline & $\mathbf{N}$ & M & Sd & $\mathbf{N}$ & M & Sd & & \\
\hline $\begin{array}{r}\text { POS Patient Sumscore } \\
t 3^{2}\end{array}$ & 18 & 10.6 & 5.7 & 19 & 7.5 & 3.9 & 0.66 & 0.063 \\
\hline $\begin{array}{r}\text { POS Sumscore relatives } \\
t 3^{3}\end{array}$ & 19 & 15.9 & 5.7 & 18 & 11.2 & 5.2 & 0.87 & 0.009 \\
\hline $\begin{array}{r}\text { POS Sumscore nurses } \\
t 3^{3}\end{array}$ & 17 & 13.6 & 6.6 & 19 & 8.9 & 5.6 & 0.77 & 0.019 \\
\hline $\begin{array}{r}\text { SOC Sumscore Patients } \\
t 3^{4}\end{array}$ & 13 & 58.5 & 18.6 & 17 & 71.4 & 29.1 & 0.54 & 0.150 \\
\hline $\begin{array}{r}F A C T-G \\
\text { FUNCTIONAL WELL- } \\
\text { BEING Patients t3 }{ }^{5}\end{array}$ & 15 & 10.6 & 3.9 & 18 & 14.4 & 5.3 & 0.82 & 0.024 \\
\hline
\end{tabular}

${ }^{1}$ p-value $(2$ sided $) *<0.050 ; * *<0.001$

${ }^{2}$ Questionnaire for assessing palliative care (POS); cumulative score: range 0 (=highest satisfaction) to 40 (=lowest satisfaction)

${ }^{3}$ Questionnaire for assessing palliative care (POS); cumulative score: range 0 (=highest satisfaction) to 44 (=lowest satisfaction)

${ }^{4}$ Sense of Coherence -13 items: MIN $=13$ MAX $=91$

${ }^{5}$ Functional Assessment of Cancer Therapy - General $($ FACT-G) $($ proficiency $0-28)$; high values $=$ high attribute proficiency

Table 3. Comparison of the Post-Mortem Questionnaire of the Nurses

\begin{tabular}{|c|c|c|c|c|c|c|c|c|c|}
\hline \multirow[b]{3}{*}{ nurses } & \multicolumn{8}{|c|}{ Study groups } & \multirow[b]{3}{*}{ p-Wert ${ }^{1}$} \\
\hline & \multicolumn{4}{|c|}{ Intervention group } & \multicolumn{4}{|c|}{ Control group } & \\
\hline & $\mathbf{N}$ & Md & Q.25 & Q.75 & $\mathbf{N}$ & Md & Q.25 & Q.75 & \\
\hline $\begin{array}{r}\text { How often did it seem that your patient had } \\
\text { his pain under control? }\end{array}$ & 15 & 4.0 & 3.0 & 4.0 & 13 & 4.0 & 3.0 & 4.0 & 0.254 \\
\hline $\begin{array}{r}\text { How often did it seem that your patient had } \\
\text { control over what was going on around } \\
\text { him/her? }\end{array}$ & 15 & 3.0 & 2.0 & 4.0 & 12 & 3.5 & 2.0 & 4.0 & 0.792 \\
\hline $\begin{array}{r}\text { How often was your patient able to eat } \\
\text { independently? }\end{array}$ & 15 & 3.0 & 1.0 & 4.0 & 11 & 3.0 & 0.0 & 4.0 & 0.919 \\
\hline
\end{tabular}


Psychotherapeutic Modalities, Methods and Methodics

\begin{tabular}{|c|c|c|c|c|c|c|c|c|c|}
\hline \multirow[b]{3}{*}{ nurses } & \multicolumn{8}{|c|}{ Study groups } & \multirow[b]{3}{*}{ p-Wert ${ }^{1}$} \\
\hline & \multicolumn{4}{|c|}{ Intervention group } & \multicolumn{4}{|c|}{ Control group } & \\
\hline & $\mathbf{N}$ & Md & Q.25 & Q.75 & $\mathbf{N}$ & Md & Q.25 & Q.75 & \\
\hline $\begin{array}{r}\text { How often did your patient seem to breathe } \\
\text { calmly? }\end{array}$ & 15 & 3.0 & 3.0 & 4.0 & 12 & 4.0 & 2.0 & 4.0 & 0.427 \\
\hline $\begin{array}{l}\text { How often did your patient seem to have a } \\
\text { satisfied feeling in the last days of his life? }\end{array}$ & 15 & 3.0 & 2.0 & 4.0 & 11 & 3.0 & 2.0 & 4.0 & 0.838 \\
\hline $\begin{array}{r}\text { How often did your patient seem fearless in } \\
\text { the last days of his life? }\end{array}$ & 14 & 4.0 & 2.0 & 5.0 & 11 & 4.0 & 2.0 & 4.0 & 0.647 \\
\hline $\begin{array}{l}\text { If there were happy moments in the last days } \\
\text { of your patient's life (e.g. when your patient } \\
\text { smiled, when you laughed together, } \\
\text { remembered beautiful experiences)? }\end{array}$ & 14 & 2.0 & 2.0 & 4.0 & 12 & 2.0 & 1.0 & 3.0 & 0.374 \\
\hline $\begin{array}{l}\text { How often did your patient seem to be able to } \\
\text { maintain their own dignity and self-esteem? }\end{array}$ & 15 & 4.0 & 3.0 & 4.0 & 12 & 4.0 & 3.0 & 4.0 & 0.719 \\
\hline $\begin{array}{r}\text { How often did your patient spend time with } \\
\text { family or friends? }\end{array}$ & 15 & 4.0 & 2.0 & 5.0 & 12 & 5.0 & 5.0 & 5.0 & 0.059 \\
\hline How often did your patient spend time alone? & 15 & 2.0 & 1.0 & 3.0 & 11 & 1.0 & 0.0 & 2.0 & 0.109 \\
\hline $\begin{array}{r}\text { How would you assess the overall quality of } \\
\text { life in the last days of your patient's life? } \\
\text { (nurse) }\end{array}$ & 15 & 8.0 & 5.0 & 9.0 & 12 & 6.5 & 5.5 & 8.5 & 0.614 \\
\hline $\begin{array}{r}\text { How would you assess the overall quality of } \\
\text { care in the last days of your patient's life? } \\
\text { (nurse) }{ }^{3}\end{array}$ & 15 & 8.0 & 8.0 & 9.0 & 12 & 9.0 & 6.5 & 10.0 & 0.373 \\
\hline $\begin{array}{r}\text { Please evaluate the quality of care your } \\
\text { patient has received from all doctors and } \\
\text { other caregivers during the last days of his or } \\
\text { her life. (nurses) }{ }^{4}\end{array}$ & 15 & 9.0 & 8.0 & 10.0 & 12 & 9.0 & 8.0 & 10.0 & 0.981 \\
\hline $\begin{array}{l}\text { Please evaluate the quality of care your } \\
\text { relative has received from his or her doctor } \\
\text { during the last days of his or her life) }{ }^{4}\end{array}$ & 15 & 8.0 & 8.0 & 9.0 & 12 & 9.0 & 7.5 & 10.0 & 0.755 \\
\hline
\end{tabular}

${ }^{1}$ p-value $(2$ sided $) *<0.050 ; * *<0.001$

2 characteristics: $0=$ never. $1=$ rare. $2=$ sometimes. $3=$ frequently. $4=$ mostly. $5=$ always

${ }^{3}$ range 0 to $10(0=$ very bad vs. $10=$ very good $)$

${ }^{4}$ range 0 to $10(0=$ worst possible care vs. $10=$ best possible care $)$

Table 4. Satisfaction with supervision broken down by occupational groups

\begin{tabular}{|c|c|c|c|c|c|c|}
\hline Nurses & $N$ & $M$ & Sd & Md & Q.25 & Q.75 \\
\hline $\begin{array}{r}\text { How satisfied were you overall with the supervision you } \\
\text { received? }\end{array}$ & 26 & 83.7 & 18.3 & 95.0 & 75.0 & 100.0 \\
\hline Could your expectations be met overall? ${ }^{a}$ & 26 & 80.2 & 16.3 & 85.0 & 75.0 & 95.0 \\
\hline $\begin{array}{r}\text { How do you assess the professional competence of the } \\
\text { supervisor? }\end{array}$ & 26 & 87.7 & 11.8 & 92.5 & 85.0 & 95.0 \\
\hline $\begin{array}{r}\text { How do you assess the social competence of the } \\
\text { supervisor? }\end{array}$ & 26 & 87.7 & 11.8 & 92.5 & 85.0 & 95.0 \\
\hline
\end{tabular}




\begin{tabular}{|c|c|c|c|c|c|c|}
\hline $\begin{array}{r}\text { Questions about personal attitude towards supervision: } \\
\text { I would recommend participation in supervision } \\
b\end{array}$ & 26 & 2.8 & 0.4 & 3.0 & 3.0 & 3.0 \\
\hline $\begin{array}{r}\text { Questions on personal attitude towards supervision: I } \\
\text { consider theme-centred supervision to be effective and } \\
\text { useful }^{b}\end{array}$ & 26 & 2.8 & 0.4 & 3.0 & 3.0 & 3.0 \\
\hline $\begin{array}{r}\text { Questions about my personal attitude towards } \\
\text { supervision: By participating in the supervision I was } \\
\text { able to make positive experiences }{ }^{b}\end{array}$ & 26 & 2.7 & 0.5 & 3.0 & 2.0 & 3.0 \\
\hline $\begin{array}{r}\text { Actual perceived improvements: Personal attitude to } \\
\qquad \text { care }^{b}\end{array}$ & 26 & 2.7 & 0.5 & 3.0 & 2.0 & 3.0 \\
\hline $\begin{array}{r}\text { Questions about personal attitude towards supervision: } \\
\text { I would continue to participate in supervision talks in } \\
\text { the future }\end{array}$ & 26 & 2.7 & 0.5 & 3.0 & 2.0 & 3.0 \\
\hline General practitioners/physiscians & $N$ & $M$ & $S d$ & Md & $Q .25$ & $Q .75$ \\
\hline $\begin{array}{r}\text { How satisfied were you overall with the supervision you } \\
\text { received? }\end{array}$ & 23 & 78.5 & 15.8 & 75.0 & 75.0 & 95.0 \\
\hline Were your expectations met overall? $^{a}$ & 23 & 72.6 & 17.6 & 75.0 & 65.0 & 85.0 \\
\hline $\begin{array}{r}\text { How do you assess the professional competence of the } \\
\text { supervisor? }\end{array}$ & 23 & 82.6 & 17.8 & 85.0 & 85.0 & 95.0 \\
\hline $\begin{array}{r}\text { How do you assess the social competence of the } \\
\text { supervisor? }\end{array}$ & 23 & 81.7 & 17.9 & 85.0 & 75.0 & 95.0 \\
\hline $\begin{array}{r}\text { Expectations of improvements: Communication within } \\
\text { the team }{ }^{b}\end{array}$ & 23 & 3.8 & 6.4 & 3.0 & 2.0 & 3.0 \\
\hline $\begin{array}{l}\text { Questions about personal attitude towards supervision: } \\
\text { I would recommend participation in supervision }\end{array}$ & 23 & 3.8 & 6.4 & 3.0 & 2.0 & 3.0 \\
\hline $\begin{array}{r}\text { Expectations of improvements: Communication with } \\
\text { patients and caring relatives }{ }^{b}\end{array}$ & 23 & 2.5 & 0.6 & 3.0 & 2.0 & 3.0 \\
\hline $\begin{array}{r}\text { Expectations of improvements: Cooperation with } \\
\text { patients and caring relatives }{ }^{b}\end{array}$ & 23 & 2.5 & 0.6 & 3.0 & 2.0 & 3.0 \\
\hline $\begin{array}{r}\text { Questions about personal attitude towards supervision: } \\
\text { I would continue to participate in supervision talks in } \\
\text { the future }\end{array}$ & 23 & 2.5 & 0.6 & 3.0 & 2.0 & 3.0 \\
\hline
\end{tabular}

${ }^{\text {a }}$ Range 0 to $100(0=$ not at all satisfied vs. $100=$ fully satisfied $)$

${ }^{\mathrm{b}}$ Range 0 to $4(0=$ totally incorrect, $1=$ always incorrect, $2=$ always correct, $3=$ totally correct)

\section{Discussion}

The WHO considers access to palliative care as a human right. In 2014, the WHO recommended that palliative care should be integrated into primary health care. To achieve this, several countries, including Italy, have successfully developed strategies for end-of-life care at national level, including a focus on primary care.

Palliative Care is an approach that improves the quality of life of patients and their families facing the problem associated with life-threatening illness, through the prevention and relief of suffering by means of early identification and impeccable assessment and treatment of pain and other problems, physical, psychosocial and spiritual (World Health Organization, 2019). If palliative care and end-of-life care is provided at local level through primary care services, a larger number of people can benefit (Tatum, 2020). The basis of the concept for nationwide palliative care is represented at local level by State Law 38 since 2010. 
The national south Tyrolean/Italian strategy for palliative care follows the WHO recommendations. These should lead to an improved quality of life (primary endpoint) and care satisfaction on the part of patients and relatives. They should also increase the stress and the quality of life of the caregivers.

The pilot study carried out in the run-up to the study already showed that relatives of carers are often uncertain as to who they should contact and with whom be able to turn topics and questions around (Engl, 2013). Therefore, the objectives of the following study were to evaluate the quality of palliative care in South Tyrol (comparison between inpatient and outpatient/domestic services). The sample consisted of patients in palliative care, one family member providing care (central reference person), one nurse (central reference person) and the family doctor. Especially the offered topic-centred supervision should lead to improvements in various areas as

- communication and conversation

- dealing with stressful situations

- contact and relationship skills

- self-concepts and stress management methods

Two groups were formed: an intervention group (with supervision) and a control group. These two groups were assigned to individual districts. The case number analysis was based on the central hypothesis that more favourable values of change in the dimensions quality of life and depression are expected in the intervention group compared to the control group.

A first aim was to find a good balance regarding the number of supervision meetings. Too frequent supervision appointments could increase stress (and thus have a negative effect on the dependent variables), too few supervision appointments would not have the desired positive effect on the dependent variables. Assuming that the intervention group is supervised for 6-10 months, supervision appointments should initially be scheduled 3-2 hours per week for 3-2 hours each. In the concrete implementation, however, these intervals between the two supervision appointments were shifted back by due to the coordination of the appointments of the professionals involved and the respective concrete situation of the survey appointments.
Practically it resulted that 2 supervision appointments were made during the patient treatment and one post mortem for each palliative group. In addition, the intervention group was asked to provide further important and relevant data on the organisation, training needs and priority issues of palliative care. In cases where palliative patients had died between the two supervision appointments, the team of experts decided to carry out the evaluation in some cases.

At the beginning of the study, the intervention group and the control group were well comparable in the vast majority of the study areas. The intervention group showed the slightly higher scores in the "SOC total score" for nurses, as well as in the "physical sum" scale in SF-12. The slightly more advantageous effect of the "SOC total score" is, however, sufficiently compensated by the statistical standard error, as in the SF-12 (Huo, 2018). The statistical standard error of the SF-12 is also known to be greater than that of the SF-36. Among physicians, the intervention group showed the slightly lower scores in the area of "Development opportunities COPSOQ" and "Community spirit COPSOQ". Here too, the slightly more favourable score is ultimately sufficiently compensated by the statistical standard error. Therefore, the only area of particular interest among general practitioners was "social support COPSOQ", in which the control group showed statistically highly significant better values. With an error probability of $5 \%$ per scale, this effect is due to the accumulation of the respective error probabilities. This is particularly underlined by the fact that the "TOTAL SCALE SOCIAL RELATIONS AND MANAGEMENT" score of the two groups was inconspicuous. Taken together, the two groups were therefore sufficiently comparable at the starting point of the study.

The palliative outcome scale (POS) is an important tool for measuring outcomes to assess the quality of life of patients and families, of the quality of care provided and the service organization. At the second test time, the "POS Sum score relatives" showed, in accordance with the literature, statistically significantly higher scores in the intervention group among relatives. In particular, the "POS Sum score nurses" in this study also showed 
the higher scores in the intervention group. The analysis of the selected scientific literature has shown that the POS is a powerful QoL assessment tool for palliative care. Its application in clinical practice also in this study could impact positively on improving the QoL of patients and families, improving quality of care, in the development and validation of other reliable instruments, in the organization of palliative care services and in the training of health professionals involved, in the early referral to palliative care (of both cancer and noncancer patients) and in the improvement of the communication / integration of the patientfamily/caregiver-professional triad (Rugno, 2016). We agree also with Capella Rugno \& De Carlo that the use of the POS as an evaluation tool, expands the understanding of health professionals about the importance of using outcome measures in evidencebased healthcare.

Several gaps remain regarding palliative care. The "FACT-G FUNCTIONAL WELL-Being Patients" score showed a rather unexpected better result for the control group. Kavalieratos et al. came to similar results. In their meta-analysis they could show that palliative care interventions were associated with improvements in patient QOL and symptom burden. Findings for caregiver outcomes were inconsistent. However, many associations were no longer significant when limited to trials at low risk of bias, and there was no significant association between palliative care and survival (Kavalieratos, 2016). However, in line with the results of this meta-analysis, we also believe that this circumstance should be further considered. In the review of Kavalieratos et al. the authors could not discern the association between specific palliative care processes and outcomes. Future research should aim to identify the efficacious component(s) of palliative care. Among subgroups for which the efficacy of palliative care has been established (e.g., oncology), future trials should consider active controls to investigate the comparative effectiveness of different palliative care strategies. Finally, trials are needed to establish optimal models of palliative care delivery that help caregivers in addition to patients. These less favourable results of the patients and relatives could thus reflect the state of health of the patients of this study group but could also be interpreted as an indirect effect of supervision on the medical and nursing activities.

Outpatient clinics provide an ideal setting within which to build trusting relationships with patients and their families, optimize symptom control issues in a timely manner and explore palliative care in a structured, longitudinal fashion in tandem with changes in the patients' cancer treatment plan. Several groups have undertaken efforts to standardize primary palliative care competencies. The post mortem analysis did not show any statistically significant results in the relationship of nurses to their patients. This was an expected result from a professional point of view and is in accordance with the accepted literature. In this respect, it can be assumed that the perception of the quality of care from a professional point of view was identical in both study groups. Moving forward, more research is needed to determine how different health systems can best personalize palliative care to provide the right level of intervention, for the right patient, in the right setting, at the right time (Hui, 2018).

Supervision itself was rated completely positively by the teams (Table 4). Both the nurses and the physicians showed extremely high approval rates. GP's even showed higher approval ratings for "Expectations of improvements: Communication within the team" and "Questions about personal attitude towards supervision". This shows a considerable benefit in medical activity when supervision is offered. There seems to be a considerable need for team cooperation. This area was rated as more important than improving communication with clients, although this area also received a very high level of approval. Periodic supervision serves a more selective care organisation in the sense of a better understanding of roles, distribution of tasks, better handling of stressful situations, prevention of burnout, and would at the same time promise multiplier effects on the quality of care and quality of life of patients and relatives. A structured team supervision with appropriately trained supervisors would certainly improve the quality of life of the participating professionals and patients in the long term. 
Regarding the supervision efforts, we conclude that the fact that the effects could only be marginally reflected in the psychometric questionnaires are probably related to a too low level of supervision. In the actual implementation, however, these intervals between the two supervision appointments were shifted backwards due to the coordination of the appointments of the participating professionals and the respective concrete situation of the survey appointments. In this respect, the extent of supervision should be determined in advance. Too many appointments have a stress-increasing or negative effect. Too few appointments have no effect. Also, willingness, need and attitude towards super revision should be assessed at the beginning. In addition, the supervision took place in two appointments and was too selective, so that statistical effects could not be determined.

From the data collected it can be concluded that a sustainable impact of supervision can usually only develop after at least 3 or more supervision meetings. A cautious introduction requires a lot of time; a direct introduction can lead to insecurity or stress. Predominant working modalities and approaches can vary, which is not to be considered a failure. It seems important to adjust the number of supervision meetings according to the needs of the individual team in order to achieve an optimized team performance.

In particular, the difference between nurses and doctors in supervision can be explained by the fact that nurses have more contact and experience with supervision. In order to promote a culture of cooperation between all those working in the palliative care sector, structured case discussions and further training with all professional participants should be offered, for example, also in areas that go beyond the catchment area for the continuous development and adjustment of support measures. These could also help to counteract the gaps in the interaction and coordination of services and professionals that still exist according to the study. These gaps in the areas of coordination and communication flow were the central theme of most of the supervision meetings.

The results of the study suggest the need for the installation of an expert panel, composed of representatives of professionals, specialist services, representatives of the hospital departments involved, and those responsible for the organisation of health care in the country. The aim should be to reflect on the organisation of palliative care and to adapt it to the current and continuously changing needs of the patients, relatives and professionals concerned, with particular emphasis on networking and communication. This is in agreement with the findings of Chang (2018). Chand underlines that support provided by supervisors and peers has a positive impact on the nursing personnel when nurses are providing hospice care for the terminally ill. Furthermore, Chang points out that sufficient support from colleagues can be an important source of comfort for clinical nursing personnel to manage their preparation for and overall strategies to cope with the death of patients.

Due to the still prevailing opinion that palliative care is associated with the immediate end of life, the palliative diagnosis of patients by professionals usually begins very late. This led to a high number of deaths during the course of the study, which also delayed the time course and completion of the study. Accordingly, this inevitably leads to difficulties in coordinating the individual professionals and medical services in networking them and in concerting the individual support and care services. This circumstance was often mentioned and discussed in the individual supervision meetings. An early palliative diagnosis would enable palliative teams, professional staff, in-patients and home care providers to better coordinate and plan home care and support. At the same time, relatives and caregivers, as well as the patient himself or herself, would be better prepared for this new phase of life or illness. A lot of awareness-raising work and training and guidance is still needed here, both in society and in health and social institutions.

According to the World Health Organization (WHO), patients with advanced cancer and other terminal diseases benefit from early identification and proactive PC (Llobera, 2017). In summary, the supervision meetings came to the conclusions that timely diagnosis leads to better coordinated palliative care and has a more favourable effect on the quality of life of the affected professionals, 
patients and relatives of caregivers, and on the course of the disease.

The results showed that supervision is an instrument that on the one hand supports and promotes teamwork, uncovers possible blind spots of the directly involved professionals, provides a critically constructive meta-view on the specific case situation and on the other hand increases the resilience of the professionals. This is also confirmed by studies conducted elsewhere on the effects of supervision.

Supervision also serves to improve the understanding of roles, the distribution of tasks, the handling of stress situations and the prevention of burnout.

\section{Limitations of the study}

In particular, it should be noted that the data acquisition was conducted over a period of 5 years. During this time, circumstances of the different teams may change, which could not be taken into account in the study. In particular, the change in the composition of teams was not taken into account. A further limitation results from the fact that the number of supervisions was not changed individually. It is therefore possible that teams may have required more supervision than it was possible to offer. Finally, it should be noted that the number of investigation instruments used was a little too high. However, this was due to the fact that, at the beginning of the study, no data on this subject was sufficiently available over such a long period of time. On the other hand, the study is therefore certainly a reference source for further studies, which should deal in particular with the optimisation of the number of team supervisions in palliative care teams. Lastly, it should be pointed out that the applied concept of team supervision is only one possible among many others.

\section{Acknowledgements}

The authors would like to thank the Institute or General Medicine, Province College for Health-Care Professions "Claudiana"; Italy for their suggestions and support.

\section{Declaration of Conflicting Interests}

The authors declared no potential conflicts of interest with respect to the research, authorship, and/or publication of this article.

\section{Funding}

This work was supported by the Institute or General Medicine, Province College for Health-Care Professions "Claudiana"; Italy. The authors received no specific grant funding from public, commercial or not-for-profit sectors.

\section{REFERENCES}

Tuppin, P., Tanguy-Melac, A., Lesuffleur, T. et al. (2019). Intensity of care for cancer patients treated mainly at home during the month before their death: An observational study. Presse Med., 48, 293-306.

Monaco, M.L., Bocchio, R.M., Natoli, G. et al. (2020). Human relationships in patients' end-of-life: a qualitative study in a hospice ward. Intern Emerg Med., 15, 975-980. https://doi.org/10.1007/s11739-019-02254-6.

McDermid, F., Mannix, J., Peters, K. (2020). Factors contributing to high turnover rates of emergency nurses: A review of the literature. Aust Crit Care, 33(4) 390-396. https://doi.org/10.1016/j.aucc.2019.09.002.

Saravanabavan, L., Sivakumar, M.N., Hisham, M. (2019). Stress and burnout among intensive care unit healthcare professionals in an Indian tertiary care hospital. Indian $J$. Crit. Care Med. 23(10) 462-466.

Engl, A., Goegele, A., Garber, K., Giacomuzzi, S.M. (2013). Palliativ-Pflege in Südtirol Ergebnisse aus der Pilotstudie - Vorbereitung für landesweite Untersuchung. $Z d S$ Krebshilfe, 3, 18-20.

Garber, K. (2010). Entwurf eines systemischen Selbst-Modells für Therapie, Coaching und Beratung. Reihe Selbst und Selbstregulation. Dresden: Jacobs Verlag.

Garber, K, Giacomuzzi, S. (2009). Short period supervision and coaching regarding the use of the 5-vector self-model. Paper presented at: XVII World International Family Therapy Association (IFTA) Congress. Portorož, Slovenia.

Langmaack, B. (1994). Themenzentrierte Supervision: einführende Texte rund ums Dreieck. Kleine Bibliothek der Psychologie. Weinheim: Psychologie-Verl.-Union.

Cella, D., Tulsky, D.S., Gray, G., et al. (1993). The Functional Assessment of Cancer Therapy scale: development and validation of the general measure. J Clin Oncol., 11, 570-579.

Yost, K.J., Thompson, C.A., Eton, D.T., et al. (2013). The Functional Assessment of Cancer Therapy - General (FACT-G) is valid for monitoring quality of life in nonHodgkin lymphoma patients. Leuk Lymphoma. 54(2), 290-297.

Stern, B., Socan, G., Rener-Sitar, K., et al. (2019). Validation of the Slovenian Version of Short Sense of Coherence Questionnaire (SOC-13) in Multiple Sclerosis Patients. Zdr Varst., 58(1), 31-39.

Burr, H., Berthelsen, H., Moncada, S., et al. (2019). The Third Version of the Copenhagen Psychosocial Questionnaire. Saf Health Work, 10(4), 482-503.

Nuebling, M., Seidler, A., Garthus-Niegel, S., et al. (2013). The Gutenberg Health Study: measuring psychosocial factors at work and predicting health and work-related outcomes 
with the ERI and the COPSOQ questionnaire. BMC Public Health, 13, 538.

Ware, J.E., Kosinski, M., Keller, S.D. (1998). SF-12: how to score the SF-12 physical and mental health summary scales. Lincoln, RI: Quality Metric Incorporated.

Rugno, F.C., Carlo, M.M.R. do P.D. (2016). The Palliative Outcome Scale (POS) applied to clinical practice and research: an integrative review. Rev Lat Am Enfermagem., 24, e2764. https://doi.org/10.1590/1518-8345.0993.2764.

Wentlandt, K., Krzyzanowska, M.K., Swami, N., et al. (2012). Referral practices of oncologists to specialized palliative care. J. Clin. Oncol., 30(35), 4380-4386.

Herrmann, C. (1997). International experiences with the Hospital Anxiety and Depression Scale: a review of validation data and clinical results. J Psychosom Res. 42, 17-41.

Montazeri, A., Vahdaninia, M., Ebrahimi, M., et al. (2003). The Hospital Anxiety and Depression Scale (HADS): translation and validation study of the Iranian version. Health Qual Life Outcomes., 1, 14. https://doi.org/10.1186/1477-7525-1-14.

Hobkirk, A.L., Starosta, A., De Leo, J., et al. (2015). Psychometric Validation of the BDI-II among HIVPositive CHARTER Study Participants. Psychol Assess., 27(2), 457-466.

Beck, A.T., Steer, R.A., Brown, G.K. (1996). Manual for the Beck Depression Inventory-II. San Antonio, TX: Psychological Corporation.

Sung, Y.T., Wu, J.S. (2018). The Visual Analogue Scale for Rating, Ranking and Paired-Comparison (VAS-RRP): A new technique for psychological measurement. Behav Res Methods., 50(4), 1694-1715.

Gräßel, E., Adabbo, R. (2011). Perceived burden of informal caregivers of a chronically ill older family member. Gero Psych., 24(3), 143-54.
World Health Organization, (2019). Retrieved from URL: https://www.who.int/cancer/palliative/definition/en/

Tatum, P.E., Mills, S.S. (2020). Hospice and Palliative Care: An Overview. Med Clin North Am., 104(3), 359-373.

Huo, T., Guo, Y., Shenkman, E., Muller, K. (2018). Assessing the reliability of the short form 12 (SF-12) health survey in adults with mental health conditions: a report from the wellness incentive and navigation (WIN) study. Health Qual Life Outcomes., 16(1). https://doi.org/10.1186/s12955-018-0858-2.

Kavalieratos, D., Corbelli, J., Zhang, D., et al. (2016). Association Between Palliative Care and Patient and Caregiver Outcomes. A Systematic Review and Metaanalysis. JAMA, 316(20), 2104-2114.

Hui, D., Hannon, B., Zimmermann, C., Bruera, E. (2018). Improving Patient and Caregiver Outcomes in Oncology: Team-Based, Timely, and Targeted Palliative Care. $C A$ Cancer J Clin., 68(5), 356-376.

Chang, W.P. (2018). How social support affects the ability of clinical nursing personnel to cope with death. Appl Nurs Res., 44, 25-32.

Llobera, J., Sansó, N., Ruiz, A., et al. (2017). Strengthening primary health care teams with palliative care leaders: protocol for a cluster randomized clinical trial. $B M C$ Palliat Care. 17(1), 4. https://doi.org/10.1186/s12904-0170217-9.

\section{ORCID IDs \\ (D)Klaus Garber, https://orcid.org/0000-0002-0958-0641 \\ (DSalvatore Giacomuzzi, https://orcid.org/0000-0001-8059-0474 \\ (DIvan Titov, https://orcid.org/0000-0002-5529-1568 \\ (D)Kira Sedykh, https://orcid.org/0000-0003-3528-7569 \\ DOlexander Kocharian, https://orcid.org/0000-0003-3439-1364 \\ (1)Natalia Barinova, https://orcid.org/0000-0001-5103-0611}

ВПЛИВ І ВИКЛИКИ СТОСОВНО НАДЗОРУ В КОМАНДАХ ПАЛІАТИВНОГО ДОГЛЯДУ: РЕЗУЛЬТАТИ 5-РІЧНОГО ДОСЛІДЖЕННЯ У ПІВДЕННОМУ ТІРОЛІ (ІТАЛІЯ) Клаус Гарбер ${ }^{1}$, Сальваторе Джакомуцці ${ }^{1}$, Катрін Гапп ${ }^{2}$, Марія Луїза Обексер ${ }^{2}$, Анна Гегеле-Бласбіхлер ${ }^{2}$,

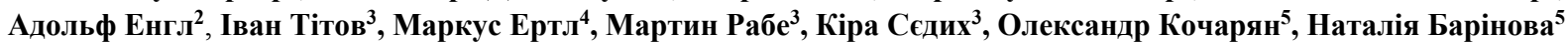
${ }^{l}$ Університет Шопрон, Угорщина; Кафедра психології Університету Зигмунда Фрейда, Відень, Австрія

${ }^{2}$ Інститут загальної медицини, провіниійний коледж медичних професій “Клаудіана”, Больияано, Італія ${ }^{3}$ Університет Шопрон, Угорщина; Полтава, Національний педагогічний університет імені В.Г. Короленка, Полтава, Украйна ${ }^{4}$ Бюро статистичних досліджень, Інсбрук, Австрія

${ }^{5}$ Харківський національний університет імені В.Н. Каразіна, Харків, Украӥна Мета: Оцінка клінічного догляду, орієнтованого на результат, для покращення якості медичної допомоги. Дизайн: Ми провели рандомізоване, довготермінове контрольоване дослідження. Загалом у дослідженні брали участь 32 райони охорони здоров'я. Для оцінки втручання в якості показників якості спостереження були зібрані наступні показники: Якість життя (FACT-G, SF12, POS), психологічний стрес, депресія, вигорання (шкали HADS, BDI-II, VAS, HPS), почуття злагодженості (SOC-13), задоволення турботою, спілкуванням та підтримкою з боку пацієнтів та родичів (шкали VAS) та умовами праці (COPSOQ) з боку медсестер та сімейних лікарів. Результати: 385 підшкал SOC для медсестер $(\mathrm{p}=0,017)$, шкала для сестринської справи SF-12 (p = 0,036) та шкала лікарів загальної практики COPSOQ показали значні відмінності у можливостях розвитку $(\mathrm{p}=0,020)$, лідерство $(\mathrm{p}=0,003)$, соціальна підтримка $(\mathrm{p}=0,001)$ та дух громади $(\mathrm{p}=0,024)$. На другому етапі дослідження були знайдені суттєві відмінності у підшкалах шкали результатів паліативної допомоги (POS) та підшкали тестового інструменту Функціональна оцінка терапії раку - загальне (FACT-G) пацієнтів. Значення задоволеності медсестер та лікарів загальної практики наглядом показали надзвичайно позитивні оцінки як медсестер, так і лікарів загальної практики щодо нагляду. Висновки: Нагляд позитивно впливає на процес паліативної домашньої допомоги. Здається важливим скоригувати кількість нарад з нагляду відповідно до потреб окремої команди, щоб досягти оптимізованої роботи команди.

Ключові слова: нагляд за командою; паліативна допомога; догляд за кінцем життя; перспективи лікаря 